Jolanta Szymkowska-Bartyzel

Institute of American Studies and Polish Diaspora

Jagiellonian University, Kraków, Poland

\title{
Harley-Davidson on Polish Roads: the Mythical Aspects of Automotive Fascination
}

\begin{abstract}
Harley-Davidson is one of the most recognizable brands of automotive products. The brand is saturated with mythical meanings which include defiance, rebellion, adventure and the desire for limitless freedom. Harley-Davidson is also a synonym of America - the motorcycle was created to make a "trip of a lifetime or a groundbreaking journey of purification," and open American spaces are the necessary condition for fulfilling this myth. In Poland, the myth of Harley-Davidson is also carefully cherished by enthusiasts, for whom Harley-Davidson is much more than just a motorcycle. This text is an attempt to analyze the functioning of the Harley myth in Poland. Some texts of Polish culture using the Harley-Davidson will be discussed as well as forms of practical implementation of Harley-Davidson passion (H-D clubs, rallies, etc.).
\end{abstract}

Harley-Davidson is undoubtedly one of the most semantically saturated brands of automotive products, a mythical brand promoting itself through concepts of brotherhood, rebellion, adventure and unlimited freedom. Harley-Davidson is also synonymous with America - a motorbike created to make a "trip of a lifetime," purifying and groundbreaking journeys for which open American spaces, crisscrossed by a network of roads, are their necessary condition. In his book devoted to Harley-Davidson, Brock Yates, one of the most well-recognized American automotive journalists, claims that even Americans who are not very emotional about their vehicles, viewing them rather from a perspective of practicality, treat their Harley in a different, very specific way, "preening it like a pet horse and espousing mystical theories about it and its quasi-human traits" (Yates xiv).

In Poland, the myth of Harley-Davidson is also very popular and very carefully cherished by enthusiasts, for whom it is much more than just a motorcycle. This text is an attempt to analyze the functioning of the Harley-Davidson myth in Polish culture. The analysis shall be based on both texts of Polish popular culture which use the Harley-Davidson legend and the implementation of the Harley-Davidson passion (clubs, rallies, lifestyle, etc.). Various aspects and phases of the development of 
Harley-Davidson mythology will be discussed, and a theory of myth will be briefly presented.

The theoretical basis for this analysis of the Harley-Davidson myth constitutes the theory of myth by Roland Barthes, who introduced one of the most insightful analyses of popular culture in which he argues that myths are not derived solely from the sphere of sacrum, but, on the contrary, the realm of profanum - the everyday reality closely surrounding us is nowadays the most creative generator of myths. Reduced, simplified and often trivial texts of popular culture are also producers of numerous myths. What's more, the structural concept of myth which Barthes presents, despite its semiotic motivation, is so universal that it is widely used in studies of contemporary culture texts.

In his reflections on myth, Roland Barthes makes use of the concept of sign by Swiss linguist Ferdinand de Saussure, for whom each sign consists of two major components: the signifier (signifiant) and the signified (signifie). The signified is an abstract concept, whereas the signifier has a material character - either a visual or acoustic form. Barthes transposes this concept of the dual structure of a sign Barthes for his analysis of myth. According to Barthes, myth "is a second-order semiological system" (114) constructed on a primary system that Barthes calls "language-object" (115) because it is the language appropriated by the myth to construct its own semiological system. The myth takes signifying of the first system, and "steals it" in order to make it meaningful in the secondary system (signifier). However, in order to avoid confusion, to the second order semiological system, the one at the level of myth, Barthes introduces additional concepts: the signifier is called "a form" and the signified "a concept," whereas a sign at this level is nothing but a "signification." Signification is the myth itself, says Barthes (121), which is a combination of a form and concept in a sign of a cultural character.

However, as Barthes points out, in contrast to a linguistic sign,

$[\ldots]$ the mythical signification is never arbitrary [...]; it is always in part motivated. [...]. Motivation is necessary to the very duplicity of myth: myth plays on the analogy between meaning and form, there is no myth without motivated form. [...]. Motivation is unavoidable. It is none the less very fragmentary. To start with it is not "natural": it is history which supplies its analogies to the form. Then, the analogy between the meaning and the concept is never anything but partial; the form drops many analogous features and keeps only a few (126-127).

The secondary order semiological system, whose final element is a myth that uses some elements of the "language-object" from which it was born, stands over it at the same time that it condenses and simplifies the language, "steals it" and selects only some elements which are to serve it. This is because, as Barthes argues: "The function of myth is to empty reality: it is literally, a ceaseless flowing out a haemorrhage, or perhaps an evaporation, in short a perceptible absence" (143). Thanks to this process, the myth transforms History into Nature (141). "What a world supplies to the myth is a historical reality, defined, even if this goes back quite a while, by the way in which men have produced or used it; and what myth gives in return is a natural image of this reality" (142). As a result, "myth is constituted by the loss of historical quality of things: in it things lose the memory that they once were made" (142). However, it does not eliminate the memory but only cleanses it, because 
[...] myth acts economically: it abolishes the complexity of human acts. It gives them the simplicity of essences, it does away with all dialectics, with any going back beyond what is immediately visible, it organizes a world which is without contradictions, because it is without depth, a world wide open and wallowing in the evident, it establishes a blissful clarity; things to appear to mean something by themselves (143).

The breeding ground for contemporary myths is popular culture. Today in late capitalist societies the products of popular culture - movies, songs, colorful newspapers and magazines, popular novels, photographs and advertisements create the mythology of a modern man. These popular cultural texts appropriate various elements of history and reality, simplify and reduce them, and rob them of depth and complexity, thus creating new semiological systems - contemporary myths. Harley-Davidson has become one of the victims of the plunder made in its history by myth.

The real history of Harley-Davidson began in 1903 when William Sylvester Harley and Arthur Davidson constructed, under the brand name Harley-Davidson, the first model of a motorcycle. In 1906, their company issued the first catalog advertising the new model of a motorcycle called the Silent Grey Fellow. This is the first important step in creating the Harley-Davidson myth - to the brief history of the motorbike, the advertising added a narration borrowed from reality other than automotive: the story of a friendship between a machine and its rider in which the motorbike becomes a pal, travelling companion and best friend.

Given the context of American culture, this friendly relationship resembles the one between a cowboy and his horse. Here in the modern, industrialized world of the twentieth century, a horse, which is an attribute of the pre-industrial era, has been replaced by a faster and more efficient, but equally "living" and co-sentient vehicle. Hence, perhaps, the still so frequent belief of Harley-Davidson motorbikes' owners that their Harley-Davidson is a "machine with a soul." The company was growing rapidly, and had gained fame even before World War I as the winner of many motorcycle races.

During World War I, Harley motorcycles were used for military purposes, and thanks to the U.S. Army they ended up on the European continent. In the interwar period, road racing and a kind of racing called "hill climbing," which involved riding into high, steep slopes, became very popular. Such races aroused the increasing interest of very enthusiastic motorcyclists, and their meetings quickly gained a very organized form called a "rally," which to this day remains the most popular form of meeting for motorcycling enthusiasts. The increasing popularity of races and rallies also led to the formation of the first motorcyclists' organizations.

Soon other, improved models of Harley-Davidson bikes were introduced to the market, and some of them were also exported to Poland. During World War II, Harley-Davidson received a government contract for delivery of its motorbikes to the U.S. Army - in 1940, the Army ordered 745 units of the Harley-Davidson model WLA, which proved to be so successful that it ended with a record of almost 90,000 units (Saladini 78). In the United States after the war, thousands of Harley-Davidson motorbikes went to army surplus along with their owners.

Veterans contributed largely to the creation of the Harley-Davidson myth. Frustrated and mentally maimed, they felt misunderstood and socially superfluous. Lost in the new reality, they felt best in the company of men who were similarly frustrated 
and disappointed. They began to gather in a peculiar kind of support group - motorcycle gangs. Brock Yates argues that motorcycle gangs were the product of the Great Depression, when workers from industrial areas of Southern California spent their hours after work on motorcycles, drinking and trading in stolen parts for their bikes. Harley-Davidson was already the most popular brand, and therefore it was most often chosen as the bike of choice as well as a source of income from theft (Yates 13). But the real boom for motorcycle gangs ${ }^{1}$ came in the second half of the 1940s.

Young people in their early twenties, who could not find a place for themselves in the post-war reality and who were familiar with modern technology after having operated tanks, planes, and trucks during the war, made motorcycles the object of their fascination, a very distinctive symbol of rebellion and a weapon against the establishment. These newly-formed clubs had strange and fearsome names: Boozefighters, the Pissed Off Bastards of Bloomington and Satan's Sinners.

The moment that significantly influenced the myth of Harley-Davidson was an event which took place between the $4^{\text {th }}$ and $6^{\text {th }}$ of July, 1947, in Hollister, a small farming town in California. According to American media, the town was invaded by over 4,000 members of motorcycle clubs (Davidson 234). The unexpected visit of the bikers soon turned into a riot during which the residents and police fought with the motorcyclists. Dozens of attendees were arrested and roughly the same number reported injuries, several even heavy. The most important, however, was the impression the event made in the small town, where for several days the number of motorcycle invaders exceeded the number of local residents. These were the facts concerning the Hollister events, but it was the texts of popular culture which built up the myth of Harley-Davidson as a rebellious, aggressive and misguided vehicle. A specific role, according to Brock Yates, was played by Life magazine, which exaggerated and dramatized the whole story, and also published a remarkable photo taken by San Francisco Chronicle photographer Barney Peterson. The photo was bought by the Associated Press Agency and Life magazine (Yates 17-18). The photo presented a young, stocky motorcyclist in an unbuttoned shirt and baseball cap with a firmly blase expression on his face, sitting on a motorcycle - without any doubt a Harley-Davidson - while holding bottles of beer in both hands. In addition, around the motorcycle there are at least a dozen empty bottles and lots of broken glass. Yates claims that this was a posed photo. Indeed, Peterson, accompanied by a reporter named CJ Doughty, arrived in Hollister on July $5^{\text {th }}$, when it was already much quieter than the previous day but they had to deliver some hot stories. The Chronicle decided to dramatize the events slightly. Peterson's photo, which was seen by many Americans thanks to Life magazine, not only built up a specific reputation for Harley-Davidson and its users but also created the myth of a machine connected to rejected, rebellious and aggressive users.

This myth was strengthened by legendary motorcycle clubs such as the Hells Angels and their wild reputations. Harley-Davidson became synonymous with the Hells Angels because it was the most popular and widely accessible motorbike in the United States. We must be aware, however, that members of motorcycle clubs also rode motorcycles of other brands such as American Indians and European Triumphs.

\footnotetext{
Brock Yates notes that young veterans associating in informal motorcycle organizations never called them gangs, but "clubs" (see Yates 15).
} 
Soon other pop culture texts added to the Harley-Davidson myth. First of all, there were two popular and nearly legendary movies.

The first was The Wild One by Laszlo Benedek from 1953 - a film that mythologized not so much Harleys but motorcycle riders themselves, creating an image for them as being arrogant and rebellious. The plot of the film makes reference to the events that had taken place several years earlier in Hollister. The main character is a young, handsome man named Johnny, played by Marlon Brando, who, along with his friends from motor clubs, "invades" a quiet American town, causing some confusion. Johnny is the leader of the group, more cheeky and provocative than his mates. When, however, he falls in love with a charming waitress, he relents and changes not only his behavior but also his views. However, the town's residents fail to see that change. For them, he is still an aggressive hooligan. As a result of this film, Marlon Brando, and his character, Johnny, became the quintessential symbol of youth rebellion, tragic misunderstanding and rejection. Not only bikers, but young people in general, identified themselves with this character, and a poster with the figure of Marlon Brando dressed in a leather jacket and sitting on a motorcycle has become a pop culture icon. Although the film is often invoked in the context of Harley-Davidson legend, it is worth noting that the main protagonist rides a British Triumph, not an American Harley-Davidson. This is a detail noticed only by a few experts in the automotive industry; for many, Harley-Davidson is so inextricably linked to the values presented by the film's main character that they are convinced Johnny rode a Harley-Davidson. Marlon Brando, as Johnny, created a perfect model of a young rebel. His opposition to the world was signaled not only by his attitude, but also by the gadgets and accessories he possessed - a leather jacket, jaunty cap and, of course, a motorcycle.

Because of its construction and design features, a motorcycle is the vehicle which most fully meets the expectations of rebels - the solitary nature of motorcycle travel, guaranteed speed and direct contact with nature allow them to sense limitless freedom.

Another movie that has been extremely meritorious in building Harley-Davidson's mythology was Easy Rider, directed by Dennis Hopper in 1969. The film became a real manifesto of the countercultural revolution that hit the United States in the 1960s. It should be noted that motorcyclists did not quite fit into the hippie movement. Members of the Hell's Angels motorcycle gang supported the Vietnam War and did not identify themselves either with the pacifism or liberal views of the flower children. Hopper's movie largely contributed to the merging of these two very different representations of youthful rebellion - the motorcycle gangs and the Flower Power.

The main protagonists of the film are two hippies applying in their lives the sacred principle of "live and let live." Billy (Dennis Hopper) and Wyatt, who is known as Captain America (Peter Fonda), are harmless to society but in love with freedom. With money from selling drugs, they go to New Orleans to take part in the Mardi Gras Festival. On their way they encounter other freedom-seekers and outsiders, but also hostile citizens: provincial bumpkins and unprofessional policemen full of prejudice and aggression towards them. The journey which was supposed to give them new experiences and discoveries brings them both death at the hands of provincial, conservative citizens who are afraid of the otherness and freedom represented by the two hippies. 
In Hopper's film, the bikes also play a very important role; as a matter of fact, they are almost equal protagonists of the story. Tuned and customized, they reflect their riders and become an extension of their personalities. Hopper's movie changed the way the Harley-Davidson brand was perceived. Instead of associations with the aggression, violence and crimes of biker gangs, it developed new connections with youth rebellion, the search for one's place in life and the desire for freedom and independence. As a matter of fact, Easy Rider redefined the Harley-Davidson myth, reinforced it and introduced the brand into the cultural mainstream for good. From the 1970s onwards, the popularity and positive reception of Hopper's film caused Harley-Davidson to gradually become attractive to those not actually rejected, misunderstood or rebelling against the establishment, but rather representatives of the latter. The youth rebellion that was inscribed in the brand was made conformist and was overtaken by the machine of consumption. This process became clear in the 1980s, when the prices of Harley-Davidson motorcycles increased significantly and they became luxury vehicles acquired not by socially and economically excluded people, but by Rolex Riders (W. Thompson 7), i.e. bankers, lawyers and doctors, those who make up the financial elite. For them, riding a Harley-Davidson has become a kind of ideologically saturated way to spend their leisure time, when they throw off their professional uniforms, take off the masks of serious managers with a high social status and become a vagabond rebel. Harley-Davidson bikes came out of the dingy garages of the suburbs and entered the exclusive city center. As Brock notes, Harley-Davidson bikes are now found in exclusive garages next to BMWs and Porches.

Brock Yates argues that the elites' interest in Harley-Davidson motorcycles is related to a search for authenticity, roughness and coarse nature, which are inscribed into Harley-Davidson bikes (45). However, it should be remembered that this elitist use of Harley-Davidson is one of the many forms of human relations with this machine. Although myth has simplified the popular perception of the motorcycle, it must be remembered that in addition to rich eccentrics, Harley-Davidson has among its users true enthusiasts, hobbyists who invest almost every dollar earned in their beloved, though not necessary newest, Harley, and they spend every spare minute with their Harleys either on solitary rides, at rallies or doing endless repairs in the garage.

This somewhat extensive introduction outlining the history of Harley-Davidson mythology was needed in order to collate it with the specificity of Polish myths concerning the American bikes. Therefore, while looking at the history of the Harley-Davidson's presence in Poland, we will trace the functioning of these motorcycles in Polish popular culture and try to define areas of similarities and differences in practices of a strictly American representation of the mythology.

In Poland, Harley-Davidsons appeared during World War I. Tomasz Szczerbicki, a well-known Polish automotive journalist and Harley-Davidson enthusiast, writes about these beginnings:

In 1917, when the United States entered the war, the U.S. military authorities ordered in the factory in Milwaukee 70,000 Harley-Davidson units [...]. After the end of the war and the restoration of our country's independence, the foundation of the motorcycle fleet in the new Polish army became American Harley-Davidson motorcycles with side carts, purchased by our government from army surplus shops (Szczerbicki 84-85). 
The origins of Harley-Davidson's presence on Polish territory are thus associated with military use. At the same time in the USA, road racing and a kind of racing called "hill climbing," which involved driving into high, steep slopes, became very popular. Soon these also became popular activities in Poland. Because racing aroused great interest and a growing number of enthusiasts, their meetings very quickly took on a highly organized form called a "rally" ("zlot" in Polish). Moreover, to this day, rallies remain the most popular form of motorcycle event.

The popularity of races and rallies also led to the formation of the first motorcyclists' organizations. In 1921, the Polish Automobile Club was founded, and at the end of 1923, the Polish Motorcycle Club, which gave rise to many similar organizations. Those who belonged to such motorcycle organizations were owners of different brands of two-wheelers, not only owners of Harley-Davidsons which, at that time, particularly in Europe, was not the most popular brand. However, in the interwar period, Harley-Davidson was available for purchase, and in the 1920s the first official representatives of the Harley-Davidson company appeared. Alexander Andrzejewski, the first official general representative of the Harley-Davidson had his headquarters in Warsaw, at 2 Świętokrzyska Street, and branches in Poznan, Lviv, Krakow, Gdansk and Katowice. Around 1927, the official representative of Harley-Davidson was acquired by the "Auto Service" company based in Warsaw, at 9 Nowy Świat Street (Echilczuk, Szczerbicki 18).

It is worth noting that at this time the Harley-Davidson brand was not subjected to myth-creating operations, and even if it were, the myths were not created by advertising. In an advertisement on the cover of Auto Magazine in June 1924, Andrzejewski advertised Harley-Davidson in the following words: "THE FASTEST, MOST PRACTICAL, MOST DURABLE AND LEAST EXPENSIVE MEANS OF TRANSPORT IS UNQUESTIONABLY THE BIKE HARLEY-DAVIDSON" (Echilczuk, Szczerbicki 17). In his advertising, the trader appealed to the practicality of the future owners. He did not build his strategy around terms such as courage, brotherhood or adventure. There is no talk of freedom or rebellion. Harley-Davidson had to be useful and cheap. Tomasz Szczerbicki, however, argues that the affordability of Harley-Davidsons at that time was not as good as the ad suggested. "Sales were moderate. The brand was known in Poland, outright adored but... the desires of customers were cooled by the prices. The vehicles were very expensive, and society after the war was impoverished. A large portion of sales went to the army [...] and state institutions (e.g. Polish Post Office, Police)" (Echilczuk, Szczerbicki 16). This passion for the brand was associated, as Szczerbicki claims, with the fact that Harley-Davidsons were commonly perceived as vehicles of the Polish Army, which at that time enjoyed an excellent reputation. "The word 'Harley-Davidson' was not only the name of a vehicle - it implied all the noble features credited to the army, and in addition, technically solid and reliable - features given to the best mechanical devices" (Echilczuk, Szczerbicki 16). It can therefore be assumed that in Polish society at that time, the myth of Harley-Davidson was based on its combat trail in WWI and the fact that it was a vehicle used by Polish soldiers. This was when motorcycles were increasingly replacing horses. So here we can also observe some analogies with the American mythology of Harley-Davidson. Just as motorcyclists used to be called cowboys on mechanical steeds in the USA, in Poland Harley was a mechanized alternative to the cavalryman's horse. It was also important that the 
Polish soldiers, and officers, in particular, had a set of features which made them soldiers: honor, courage, bravery, brotherhood, nobility and impeccable manners. All of these features were also taken over by soldiers' attributes: uniform, weapons (especially melee weapons, cold steel), horses or motorcycles. The Harley-Davidson, in the Polish reality of the interwar period, became a mythical system. Implementing Barthes's theory of myth in this particular case, we see Harley-Davidson as a sign and the end product of the first language system, and at the same time it becomes a signifier in a mythical system, a form as Barthes wants, which in conjunction with the signified, in this case the signified being the idea of Polish militarism, creates a new semiological system - a myth. A myth that acts as a war looter stealing elements from the history of Harley-Davidson and by simplifying and reducing it deforms its importance. Filling the narration of Harley-Davidson with traits attributed to Polish soldiers proves to be extremely important in the subsequent years of Poles' relations with this brand of motorcycle.

The interwar period was also a time of intensive development in recreation and sports motorcycling. The organizing of various types of motorcycle competitions, rallies and races in various categories, but also tourism motorcycling, made the Harley-Davidson brand extremely popular and respected in Poland.

World War II interrupted the peace service of Harley-Davidson. Not only motorcycles that equipped the army participated in the war, but also "mobilized" civilian units. Under the Lend-Lease Act, signed in March 1941, almost 30,000 Harley-Davidsons were sent by Americans to the Soviet Army. They were to reinforce the fight against the Nazis. In 1944, soldiers of the Soviet Army and the Polish People's Army drove into Polish territory, inter alia, on Harley-Davidson WLA motorcycles.

After the war, there were many Harleys on Polish roads, since, until the 1960s, they were in service with the Polish Army. Not only soldiers rode the motorcycles, but also policemen, foresters and postmen. This miraculous reality of American machines in times ideologically hostile to them illustrates Czesław Petelski's movie from 1958, The Depot of the Dead (Baza ludzi umartych), based on a novel by Marek Hłasko called Next Stop - Paradise. The film is set in Bieszczady, a Polish wilderness region located in the eastern part of the country, among desperadoes working in vile conditions in a coal-based transport company, who see the senselessness of their work and only dream of escaping. Their monthly salary is delivered on a Harley-Davidson WLA by a messenger from the headquarters of the company. And although the motorcycle itself was in no way the hero of the story, the movie perfectly illustrates how Harleys, stripped of their myth, have been harnessed in the process of rebuilding the country. In these circumstances, the myth did not find the right conditions to develop; what counted was the durability and usefulness of the vehicles.

This situation changed in the late 1960s when Harley-Davidsons were demobilized, the political climate in Poland became a bit lighter and youths all over the world demanded revolutionary changes. In Poland, the iron curtain successfully defended Poles against an excess of consumer goods, but failed to stop news of the youth rebellion.

It was young Poles who used old Harley-Davidsons to manifest their objection to the surrounding reality. However, while in the West the Harley-Davidson symbolized a rebellion against the establishment, a particular lifestyle, defiance and 
maladjustment, in Poland to all of these determinants included in the category of youthful rebellion, revolt against the political system should be added. American products unavailable and banned in communist Poland became like forbidden fruit, and their use was considered a political manifestation. America, as the ideological enemy of communist authorities, for most young people was an imaginary paradise, a country of freedom, true democracy, prosperity and modernity. Harley-Davidson was part of this America. It was officially hated, but secretly worshiped and adored. This is why, in the Polish reality, American motorcycles, like many other items from the USA, were symbols of ideological revolt, strongly associated with the political situation, but also ordinary, youthful rebellion. In many countries of the communist bloc, the two rebellions were coupled together - very often manifestations of youthful revolt became political manifestations and often contrary to the intentions of the rebels. This was mainly because the youths, in presenting their own individuality and rejection of the existing order, used the symbols and items of American culture, which were hostile to the dominant communist ideology.

Although the rebellion of Polish youth was not as categorical as the rebellion of young Americans, and in the Polish People's Republic motorcycle gangs were not officially heard of, the fascination of young Poles with wheelers was common, and Junak, the only four-cylinder motorcycle produced in the People's Republic in 1956-65, called "the Polish Harley," was the object most dreamed of by many young boys. However, in 1971, a Polish movie was made that referred to the idea of motorcycle gangs. Five and a Half of Pale Joe (Pięć i pót bladego Józka), directed by Henryk Kluba and based on Wiesław Dymny's screenplay, tells the story of a young journalist who is writing an article about gangsters going around on Harley-Davidsons and terrorizing a small provincial town. With the help of one of the members of the gang, he manages to restore order in the town, and convinces the gang to end their criminal activities and start a decent life.

The film, made in a ballad convention, is neither a masterpiece of film art nor a cult film. Film critics consider it to be a typical "produkcyjniak" - a genre implementing the poetics of socialist realism dedicated to the theme of the system transformation in the country. Ideology is quite intrusive in this movie. It was also accused of being detached from reality. Harley-Davidsons, which play an important role in the movie, were not seen on Polish streets in large cities, not to mention small provincial towns. Undoubtedly, Kluba appealed here quite clearly to the ideas of American popular culture concerning motorcyclists, and both Kluba and Dymny drew from Hopper's Easy Rider. It is worth noting that the users of American motorcycles are, in this story, presented as aggressors, and their machines as vehicles of foreign (Western) evil, which is why the local community wants to get rid of them at any price.

Harley-Davidson is presented quite differently in Harley's Story (Opowieść Harleya), a film made in 1988, directed by Wiesław Helak. A different socio-political atmosphere - the following year would bring radical political changes - meant that Harley was presented as a symbol of freedom, a vehicle emphasizing the rebellious and unconventional personality of motorcyclists, who also, thanks to this wonderful machine, gain social esteem, self-confidence and, most importantly, the love of a girl who prefers a rebel dressed in a leather jacket with the Harley-Davidson logo on it, to a respectable engineer in a white Mercedes. The film, though not an outstanding 
masterpiece, for many young Poles on the eve of transformational change was a cult film, while Harley-Davidson was a symbolic vehicle that led this generation to a different reality. Helak's film clearly shows that the fascination with Harley-Davidsons struck not only one generation, and that the values it symbolizes are of a universal nature.

One of the main characters leaves hostile Communist Poland in his old Harley-Davidson, which he renovated himself, and goes abroad in search of a better life. He returns after many years on a new model of the same brand of motorcycle, earning the respect of all the town's inhabitants. When his fiancee, abandoned years before, rejects him, he decides to give his Harley-Davidson to a young boy, who, thanks to the motorbike, wins his beloved girl. It is a banal story, which, however, shows what an important symbolic role Harley-Davidson played and how its myth functioned in Polish culture, reducing the whole history of Harley-Davidson to the narration of freedom, independence and non-conformism. All these values in the times of the Polish People's Republic were hugely desirable, and thus also their symbolic presentation with the use of a motorcycle.

Symbolic saturation of the Harley-Davidson brand made young Poles become very passionate about the bikes. At the beginning of the 1970s, a rapid emergence of motorcycle clubs could be observed. Young people rescued Harley-Davidson motorbikes that were doomed to oblivion, they discovered them in villages and on farms, and spent months carefully renovating them. Then they organized themselves in numerous clubs of Harley-Davidson enthusiasts. The most important club in Poland was the Warsaw-based Helios club, formed in 1970, which, like other clubs, was illegal. It could not officially use the name Harley-Davidson, but it effectively infected other enthusiasts and assisted in organizational initiatives in other parts of Poland. Wojciech Echilczuk writes: "The binding rules in the club were very simple: one for all and all for one - friendship for life, ruthless honesty, patriotism of free Poles and away with the communist system!" (Echilczuk, Szczerbicki 250). The Warsaw club held the first organized International Congress of Bikers in Poland. It took place in 1971 at Hańcza Lake. From then on, such meetings were organized regularly.

Not only Poles participated in the meetings, but also Harley-Davidson lovers from other Eastern bloc countries, mainly Czechoslovakia, and from some Western European countries, especially from Holland. At that time, Harley-Davidson riders were simply very passionate about their motorcycles. Although they organized numerous meetings and rallies, there was not a trace of aggression in their activities. They did not resemble American motorcycle gangs in any way; they mainly focused on exchanging experiences and spending time together either on common repairs of their motorcycles or on shared travels. These organizations resembled the meetings of amateur hobbyists more than aggressors who wanted to change the world order. This does not mean, however, that Polish Harley-Davidson lovers accepted the reality, but it seems that they focused on their passion because of disagreement with and contestation of the socio-political situation in Poland. Their Harley-Davidson passion arose from politically hostile American culture and therefore their hobby had the flavor of conspiracy and rebellion, but it was a passive rebellion, concentrating rather on creation of an alternative reality than on demolition of the existing one. Even the regime-backed newspapers wrote about Harley-Davidson riders, warmly perceiving them as cheerful, crazy youths (Echilczuk, Szczerbicki 270-271). 
In 1989, communism ended in Poland, and the laws of a free market economy began to apply. These two aspects of the changes are essential for the Harley-Davidson myth in Poland. Firstly, the motorbikes lost their status of an anti-system symbol, and secondly the Harley-Davidson company opened its representative office in Poland. Soon Harleys ceased to be rare, inaccessible and mysterious. They have become a product, a vehicle that can be purchased like any other vehicle. They have become a luxurious product sold with the use of global strategies and an advertising narration proven to be successful in other markets. This narration still makes reference to rebellion, freedom, and brotherhood, and it sells motorbikes to wealthy clients. Harley-Davidson, from a brand of rebellious outcasts and twisted enthusiasts, has become an object of desire for wealthy people. Poland has thus joined the global trend. In Poland, like in other European countries, "harleying" is practiced by middle-aged men who perhaps, thanks to this wonderful machine, want to relive their youth, experience a true adventure or male friendship and see admiration in the eyes of beautiful women. These values and desires have remained unchanged for bikers. What definitely has changed is the intensified presence of the phenomenon called Harley-Davidson culture. Thanks to the company's entry into the Polish market, a network of showrooms selling various models of Harley-Davidson motorcycles was established, and with the showrooms a corporate marketing strategy was initiated, a strategy promoting the building of consumer communities based on HOG clubs. Every owner of a Harley-Davidson motorcycle can become a member of a club that offers him not only specific privileges and participation in events, but a whole lifestyle, including an axionormative system. Supervised by the Harley-Davidson corporation, the HOG clubs are responsible for maintaining the great mythology of the motorcycle, a mythology which grew out of rebellion and revolt but which has led to the most conformist consumer behavior, turning customers into followers of the cult which interestingly makes them believe that they are individuals, non-conformists, rebellious, special and unique, just like the motorcycles they ride, while in fact they are only loyal consumers. Brilliant marketing strategy based on promoting a particular lifestyle, values and philosophy is expressed in one of the advertising slogans promoting the brand: "Build your bike - build your freedom." The marketing concept promoting motorcycle customization to suit customers' needs, both in terms of technical parameters and motorcycle décor, allows Harley-Davidson users to fulfill their needs for individuality, expression of their personality and uniqueness. Although highly commercialized and controlled by a corporation, the Harley-Davidson myth in Poland is alive and well. Nevertheless, according to real enthusiasts, those who built and cherished the mythology of the American motorcycle in the times of communist Poland, the free market has deprived both the motorcycles themselves and their riders of mystery, uniqueness, and, above all, authenticity.

\section{References}

Barthes, Roland. Mythologies. New York: Hill and Wang, 1995.

Baudrillard, Jean. Selected Writings. Stanford: Stanford University Press, 1988.

Davidson, Jean. Growing Up Harley Davidson: Memoirs of a Motorcycle Dynasty. Stillwater: Voyageur Inc., 2001. 
Echilczuk, Wojciech, and Tomasz Szczerbicki. Harley My Pal. Warszawa, 2010.

Frank, Thomas. The Conquest of Cool: Business Culture, Counterculture, and the Rise of Hip Consumerism. Chicago: University of Chicago Press, 1998.

Heath, Joseph, and Andrew Potter. The Rebel Sell: Why the Culture Can't be Jammed. Toronto: Harper Collins, 2005.

Henshaw, Peter. Harley-Davidson: sto lat legendy. Trans. Marek Janiak. Motopublika Wydawnictwa Motocyklowe, 2002.

Holt, Douglas B. How brands become icons - the principles of cultural branding. Boston: Harvard Business School Publishing Corporation, 2004.

Renshaw, Scott W. "The Dew (Do) Generation: Explorations in Identity and Social Activism." International Journal of Humanities \& Peace 1 January, 2005: 44-46.

Roszak, Theodore. The Making of Counter-Culture: Reflections on the Technocratic Society and Its Youthful Opposition. Berkeley, Los Angeles, London: University of California Press, 1995.

Rymarczyk, Piotr. "Kontrkultura - utopia zrealizowana?" Rewolucje 1968. Warszawa: Agora S.A. and Zachęta, Narodowa Galeria Sztuki, 2008: 35-42.

Saladini, Albert, and Pascal Szymezak. Harley Davidson: History, Meetings, New Models, Custom Bikes. New York: Barnes \& Nobel, 1997.

Stachówna, Grażyna. "Henryk Kluba - mistrz filmowej ballady." Autorzy kina polskiego. Ed. Grażyna Stachówna and Bogusław Zmudziński. Kraków: Wydawnictwo Uniwersytetu Jagiellońskiego, 2007: 129-155.

Szczerbicki, Tomasz. "Historia polskiego motocyklizmu i jego związków z Ameryką." Kurier 29-31 October 2004: 84-85.

Thompson, Hunter. Hell's Angels: A Strange and Terrible Saga. London, New York: Penguin Books, 2003.

Thompson, William. Hogs, Blogs, Leathers and Lattes: The Sociology of Modern American Motorcycling. Jefferson: McFarland \& Company, Inc. Publishers, 2012.

Williams, Mark. The Classic Harley. London: Salamander Books, 1993.

Willis, Paul. Profane Culture. London: Routledge \& Kegan Paul Ltd., 1978.

Yates, Brock. Outlaw Machine. Harley-Davidson and the Search for the American Soul. New York: Broadway Books, 1999. 